into a teacher par exellance. Wilhelm Schlag (PhD '96), now at Princeton, said, "The most remarkable features of his teaching only became clear later, when I had to teach classes myself. His teaching was fresh and original-most of the proofs were his own, even if they were of well-known theorems. Of course, he was far too modest to mention this." Outside of class, "he was always available to offer his opinions and insights. He enjoyed talking mathematics with anyone, even if they didn't know much about the subject. He inspired with his enthusiasm for research and teaching."

Added Markus Keel, Caltech's Olga Taussky-John Todd Instructor in Mathematics, "Tom's unflinching honesty and bracing lack of self-consciousness set his classes far, far apart. Tom would speed into the room, looking for all the world like he'd just wrestled about 300 alley cats, half of whom were wielding squirt guns loaded with coffee. He'd distribute six or seven pages of immaculate notes which he had typed up, and apologize for a typo or two while handing them around. The lecture that would follow is impossible for me to describe in concrete terms-I really don't know how he did what he did, but it made me realize the courses I'd taken (and taught) up until then were, at their best, a lot like taxidermy: the stuffing of a slain, beautiful animal to make it look real. As in those little scenes you see in outdoor stores, a glasseyed grizzly would stand menacingly on its rear legs with a salmon impaled on its claws. If the instructor was really good, it seemed as though the bear was looking at the student while simultaneously chomping into the fish. In Tom's hands, the grizzly would rumble into full life, drop the plastic fish some fool had pasted to its paws, and wreak havoc on the yuppie Patagonia displays in the menswear department... There was something both terrific and terrifying about Tom's course."

Wolff's drive to share and his intellectual honesty made him an ideal colleague as well, said Garnett. He was always generous with his advice, but when you told him your ideas on a problem, the problem remained yours. You could be sure he would not go home and try to solve the problem for himself.

Among Wolff's professional honors were the 1999 Bocher Prize, the 1985 Salem Prize, a Sloan Fellowship, invited named lecture series at the University of Chicago and Stanford, and invited addresses at what Makarov calls "the Olympics of mathematics," the International Conference of Mathematicians in 1986 in Berkeley and 1998 in Berlin.

On the personal side, Wolff was a skilled mountaineer who climbed many peaks in the eastern Sierra solo, or with Shubin and CSUN math professor John Dye. "Some of the best times we had were while climbing," she said. He was also an enthusiastic, if less skilled, cellist. Colin Carr, his brother-in-law, told about his mom going up to Berkeley to visit him at grad school. "As you know, Tom wasn't very concerned about the comforts of home, and his room was a horrible mess. There was a sleeping bag on the floor, and on the bed was his cello."

In addition to his wife, he is survived by sons James, 3 , and Richard, 5; parents Frank and Lucile; and sisters Virginia and Caroline. A fund has been established for the boys' education; for more information contact Cherie Galvez in the math department office at (626) 395-3744 or cgalvez@its.caltech.edu.

\title{
Books
}

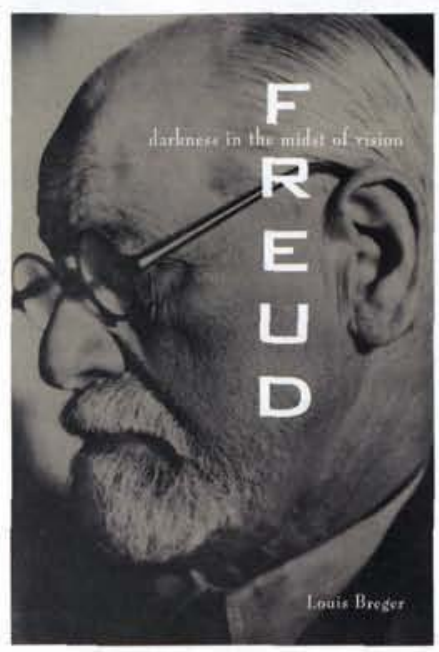

by Leslie Brothers, MD, Associate Research Neurobiologist, Department of Psychiatry, UCLA School of Medicine

Freud: Darkness in the

\section{Midst of Vision}

by Louis Breger

John Wiley \& Sons, Inc., 2000

472 pages
Sigmund Freud inspires mixed feelings, sometimes strong ones. Within recent memory such notions as the Oedipus complex, repression, and the tripartite model of the mind (id, ego, superego) have been embraced as hallowed truths - not only by psychologists, but also by social scientists, humanities scholars, and others. At the same time, however, psychoanalysis was and is ridiculed as pretentious mumbo-jumbo practiced by cultish headshrinkers. The coarser kinds of lampooning have been complemented by sober, rigorous debunking on the part of skeptical philosophers and sociologists. Citing flaws of logic and evidence, they have successfully demolished Freudian theory's claims to scientific status.

Debunked or not, Freudian ideas persist in everyday conversations about people and their motives. Common examples include the idea that it is healthy to "release" 
The authoritarian style has been adopted by generations of psychoanalysts and by the major

psychoanalytic organizations, to the serious detriment of both patients and would-be innovators-

and therefore ultimately to the movement itself.

aggression (this derives from the so-called hydraulic model, according to which aggression and libido were powerful forces seeking expression), or the idea that people behave as they do because of their "conflicts." And Freud's influence continues to be felt in intellectual circles as well. For example, neuroscientists sometimes invoke his name in their accounts of brain and mind, suggesting he dimly glimpsed truths that can now be grounded in the brain's biology. Inside and outside academia, reverence and deep distrust compete.

Why do Freud's theories continue to exert such fascination? The key may be their source, the man himself, as he is revealed in a new book by Caltech professor of psychoanalytic studies, emeritus, Louis Breger entitled Freud: Darkness in the Midst of Vision. There Breger lays bare the relationships between Freud's deep personal difficulties, his theories, and the movement he founded. In contrast to previous biographies written by Freud's devotees, Breger's Frend is a penetrating, unsettling look at the most important determinant of Freud's thought-his character. This carefully researched portrait has drawn praise from Freud's grand- daughter, Sophie Freud, for its compassion as well as its accuracy.

Breger portrays the young Freud as growing up amidst the insecurity of his easygoing father's chronic financial difficulties and his mother's numerous confinements in the family's cramped quarters. Turning in disappointment from his father's weakness, the young Sigmund developed a fascination for the heroic, identifying with such military figures as Hannibal, Alexander the Great, and Napoleon. He was able to realize his striving to be a conqueror, rather than the struggling offspring of an ineffectual father and preoccupied mother, through his intellectual gifts, which were recognized and encouraged.

His mother, although she was too emotionally limited to be nurturing, idealized him, calling him her "golden Sigi." Like the exploits of the conquerors he so admired, the theories he developed in maturity were imperial in their reach.

Further, Freud rewrote his own life to make himself a hero, eliminating whenever possible episodes that revealed his vulnerability or inadequacy. Tragically, as Breger shows, a compelling need to be in the right ren- dered humility impossible when it was needed. For example, because Freud insisted on ignoring the actual, real-life predicament of his patient Dora, she ceased cooperating with the treatment: her rejection of him became the occasion for still another theory about her unconscious motives, rather than a call to reexamine his own behavior. This he was unable to do.

Breger also carefully documents Freud's complete intolerance for anything less than total adulation and compliance on the part of his students. Freud cast aside and viciously attacked the brilliant psychoanalysts Otto Rank and Sándor Ferenczi, among others, for daring to think independently. He was aided in his vengeful acts by an inner circle of loyalists including Karl Abraham and Ernest Jones, who remained in his good graces by submitting to his control. Breger methodically removes the mask Freud constructed, showing that ruthless domination characterized not only his professional relationships but also his home life, his relations with women, and his work with patients.

Freud attributed an Oedipal neurosis to himself, and made of it a universal.
Breger's argument, that Freud's core issue was instead a lifelong effort to replace vulnerability and inadequacy with invincible grandeur, is persuasive. Breger also emphasizes some of the pernicious ramificarions of Freud's self-deception. The authoritarian style has been adopted by generations of psychoanalysts and by the major psychoanalytic organizations, to the serious detriment of both patients and would-be innovators - and therefore ultimately to the movement itself.

Perhaps we instinctively resonate to the kernel of dangerous grandiosity in Freud's proposals, and are both attracted and disturbed by it. What emerges from this compelling biography is that if Freud is in some sense larger than life it is because he was driven to be. Breger's account should be read by everyone who has loved, hated, or merely been intrigued by Sigmund Freud. 